\title{
Ecosystem engineering by different seagrasses in the Caribbean: Editorial comment on the article "Little giants: A rapidly invading seagrass alters ecosystem functioning relative to native foundation species" by Muthukrishnan et al. (2020)
}

\section{Christian Wild ${ }^{1}$}

Published online: 19 May 2020

(c) The Author(s) 2020

Seagrasses are important ecosystem engineers in shallow coastal areas. They provide habitat for associated organisms (autogenic engineering) and modify the biophysical environment (allogenic engineering) (e.g., Gutiérrez et al. 2011). In the Caribbean Sea, three native seagrasses-Thalassia testudinum, Syringodium filiforme and Halodule wrightiiengineer important meadow ecosystems that include beneficial functions, i.e. ecosystem services like coastal protection, provision of fish nursery grounds, water purification, and nutrient recycling (Ziegler 1999; Beck et al. 2001; Barbier et al. 2011). The study by Muthukrishnan et al. (2020) now investigates how another seagrass, Halophila stipulacea that originates from the Indian Ocean, could change ecosystem functions in the Caribbean Sea. This particular seagrass, although comparably small in size, is a very successful species, likely because of its ability to overcome nutrient scarcity (Cardini et al. 2018). This observation, together with the engineering role of $H$. stipulacea, justifies the use of the term "little giants".

H. stipulacea invades the Caribbean Sea among other regions since about 1 decade (Willette and Ambrose 2009; Willette et al. 2014). The pilot study by Muthukrishnan et al. (2020) conducted in the US Virgin Islands National Park thereby combines two hot topics in marine biology: ecosystem engineering and invasive species. It uses field surveys of seagrass abundance change in comparison to native seagrass species. This is complemented by bioassays to evaluate how replacement of native seagrasses by $H$. stipulacea may change ecosystem functioning. The study is highly relevant and timely due to the recent spread of $H$. stipulacea to many

Christian Wild

Christian.wild@uni-bremen.de

1 Marine Ecology Department, Faculty of Biology and Chemistry, University of Bremen, Bremen, Germany new regions. There are pronounced gaps of knowledge on the functional impact of its spread, not only for the Caribbean, but also other areas, e.g. the Mediterranean Sea where H. stipulacea competes with the endemic seagrass Posidonia oceanica (Gambi et al. 2009).

The aim of the study by Muthukrishnan et al. (2020) is unique in that a different than usual approach to the evaluation of invasive engineering species is used. This is achieved by the assessment of multiple processes-particularly resource support for higher trophic levels and habitat creation for associated organisms - that inform on ecosystem functioning. Thereby, a very valuable ecosystem-wide view to the management of seagrass habitats is provided as the spread of invasive species is a major component of global ecological change. How and when to manage particular species is an essential, yet difficult, question to answer. Ideally, such management decisions should be based on the specific impacts of invading species including both their effects on native competitors and how they may or may not play similar roles in broader ecosystem functioning. The study by Muthukrishnan et al. (2020) very well contributes to this context.

Acknowledgements Open Access funding provided by Projekt DEAL.

Open Access This article is licensed under a Creative Commons Attribution 4.0 International License, which permits use, sharing, adaptation, distribution and reproduction in any medium or format, as long as you give appropriate credit to the original author(s) and the source, provide a link to the Creative Commons licence, and indicate if changes were made. The images or other third party material in this article are included in the article's Creative Commons licence, unless indicated otherwise in a credit line to the material. If material is not included in the article's Creative Commons licence and your intended use is not permitted by statutory regulation or exceeds the permitted use, you will need to obtain permission directly from the copyright holder. To view a copy of this licence, visit http://creativecommons.org/licenses/by/4.0/. 


\section{References}

Barbier EB, Hacker SD, Kennedy C, Koch EW, Stier AC, SB R (2011) The value of estuarine and coastal ecosystem services. Ecol Monogr 81:169-193. https://doi.org/10.1890/10-1510.1

Beck MW, Heck KL, Able KW, Childers DL, Eggleston DB, Gillanders BM, Halpern B, Hays CG, Hoshino K, Minello TJ, Orth RJ, Sheridan PF, Weinstein MP (2001) The Identification, Conservation, and Management of Estuarine and Marine Nurseries for Fish and Invertebrates. Bioscience 51:633-641

Cardini U, van Hoytema N, Bednarz VN, Al-Rshaidat MMD, Wild C (2018) N2 fixation and primary productivity in a red sea Halophila stipulacea meadow exposed to seasonality. Limnol Oceangr 63(2):786-798. https://doi.org/10.1002/lno.10669

Gambi MC, Barbieri F, Bianchi CN (2009) New record of the alien seagrass Halophila stipulacea (Hydro-charitaceae) in the western Mediterranean: A further clue to changing Mediterranean Sea biogeography. Mar Biodivers Rec 2:e84. https://doi.org/10.1017/ S175526720900058X

Gutiérrez JL, Jones CG, Byers JE, Arkema KK, Berkenbusch K, Commito JA, Duarte CM, Hacker SD, Lambrinos JG, Hendriks IE, Hogarth PJ, Palomo MG, Wild C (2011) Physical ecosystem engineers and the functioning of estuaries and coasts. Treat Estuar Coast Sci 1:53-81

Muthukrishnan R, Chiquillo KL, Cross C, Fong P, Kelley T, Toline CA, Zweng R, Willette D (2020) Little giants: a rapidly invading seagrass alters ecosystem functioning relative to native foundation species. Mar Biol (to be included)

Willette DA, Ambrose RF (2009) The distribution and expansion of the invasive seagrass Halophila stipulacea in Dominica, West Indies, with a preliminary report from St. Lucia Aquat Bot 91:137-142. https://doi.org/10.1016/j.aquabot.2009.04.001

Willette DA, Chalifour J, Debrot AOD, Engel MS, Miller J, Oxenford HA, Short FT, Steiner SCC, Védie F (2014) Continued expansion of the trans-Atlantic invasive marine angiosperm Halophila stipulacea in the Eastern Caribbean. Aquat Bot 112:98-102. https ://doi.org/10.1016/j.aquabot.2013.10.001

Ziegler S (1999) Nutrient cycling in the water column of a subtropical seagrass meadow. Mar Ecol Prog Ser 188:51-62

Publisher's Note Springer Nature remains neutral with regard to jurisdictional claims in published maps and institutional affiliations. 